\title{
Do Audit Case Selection, Supervision Monitoring and Auditors' Characteristics Influence Tax Auditors' Effectiveness?
}

Erlane K Ghani, Maz Ainy Abdul Azis, Nurmashita Shamsudin, Azleen Ilias

To Link this Article: http://dx.doi.org/10.6007/IJARBSS/v11-i9/10923

DOI:10.6007/IJARBSS/v11-i9/10923

Received: 11 July 2021, Revised: 13 August 2021, Accepted: 29 August 2021

Published Online: 20 September 2021

In-Text Citation: (Ghani et al., 2021)

To Cite this Article: Ghani, E. K., Azis, M. A. A., Shamsudin, N., \& Ilias, A. (2021). Do Audit Case Selection, Supervision Monitoring and Auditors' Characteristics Influence Tax Auditors' Effectiveness? International Journal of Academic Research in Business and Social Sciences, 11(9), 1778-1795.

Copyright: (C) 2021 The Author(s)

Published by Human Resource Management Academic Research Society (www.hrmars.com)

This article is published under the Creative Commons Attribution (CC BY 4.0) license. Anyone may reproduce, distribute, translate and create derivative works of this article (for both commercial and non-commercial purposes), subject to full attribution to the original publication and authors. The full terms of this license may be seen at: http://creativecommons.org/licences/by/4.0/legalcode

Vol. 11, No. 9, 2021, Pg. 1778 - 1795

Full Terms \& Conditions of access and use can be found at http://hrmars.com/index.php/pages/detail/publication-ethics 


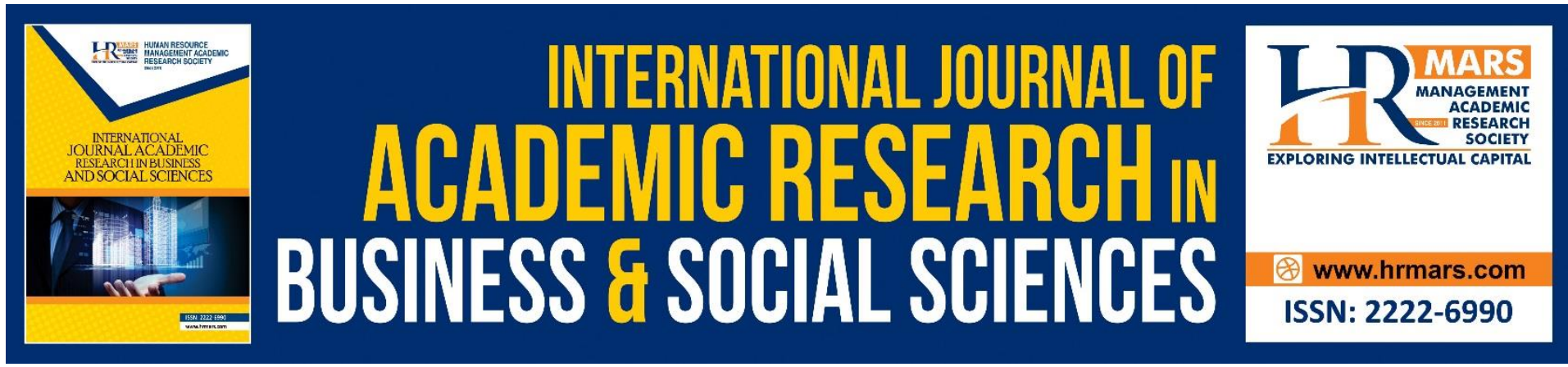

\title{
Do Audit Case Selection, Supervision Monitoring and Auditors' Characteristics Influence Tax Auditors' Effectiveness?
}

\author{
Erlane K Ghani ${ }^{1}$, Maz Ainy Abdul Azis ${ }^{2}$, Nurmashita \\ Shamsudin ${ }^{3}$, Azleen Ilias ${ }^{4}$ \\ ${ }^{1,2,3}$ Faculty of Accountancy, Universiti Teknologi MARA Selangor, Malaysia, ${ }^{4}$ College of \\ Business and Administration, Universiti Tenaga Nasional, Malaysia \\ Email: Maz731@uitm.edu.my
}

\begin{abstract}
Tax collection serves as an important source of revenue for the government of which, can be highly influence by the ability of tax auditors in performing their tasks. This study aims to examine the factors influencing tax audit effectiveness of the tax auditors in the Inland Revenue Department in Malaysia (IRBM). Specifically, this study examines whether audit case selection, supervision monitoring and auditors' characteristics influence tax audit effectiveness in of the tax auditors in the Inland Revenue Department in Malaysia. Using questionnaire survey distributed to tax auditors, this study shows that all the factors chosen in this study namely, audit case selection, supervision monitoring and auditors' characteristics significantly influence tax audit effectiveness among the tax auditors in IRBM. The findings in this study could help tax administrators to monitor IRBM's tax auditors to increase their efficiency. The results are expected to assist IRBM in identifying factors contributing efficiency and competency among IRBM tax auditors. This may enhance further steps and actions to improve level competency among the IRBM's tax auditors to help achieve its aspiration to be the leading tax administrators in the world. It will also help IRBM to consider the suggestion and recommendation in order to produce good and competence tax auditors in the future.
\end{abstract}

Keywords: Audit Case Selection, Supervision Monitoring, Auditors' Characteristics, Tax Audit, Inland Revenue

\section{Introduction}

Tax compliance has always been an ultimate goal for tax administrators all over the world. Sapiei and Kasippilai (2013) defined tax compliance as the accurate reporting of income and claiming expenses in accordance with the stipulated tax laws. Tax compliance also can be defined as the degree to which a taxpayer complies or fails to comply with the tax rules of their countries. In other words, taxpayers who have been complying perceive this as a legal and social obligation whilst non-taxpayers beg seem to disagree as their will do their best to avoid tax. The amount of tax collected is used to finance the expenditure in developing infrastructure and facilities of the country, which benefits the resident of the country. Therefore, it is important for the taxpayers to voluntary report their income, comply with tax 
laws and regulations, and ultimately, pay the tax. On the other hand, tax non-compliance might be caused by the high amount of tax payable, misappropriation of business income and the perception of huge spending on unprofitable projects by the government (Ghani \& Said, 2010). In addition, tax evaders think that despite the penalty being imposed for noncompliance, there is a low probability for them to be caught for non-conformance of tax laws and some taxpayers are also in the opinion that they are not getting a fair share of benefits from the tax payment they paid.

The introduction of the self-assessment system (SAS) in 2001 to replace the official assessment system (OAS), is a major reform of Malaysian tax system since the inception of the Income Tax Act (ITA) in 1967. The SAS imposes greater accountability upon the taxpayers in terms of computational, record keeping and requirements. The main reason for introducing SAS is to improve the compliance level amongst taxpayers, reduce the compliance cost, expedite the issuance of a notice of assessment and facilitating the collection of taxes (Singh \& Bhuplan, 2001). Under this system, the taxpayers are required to register, calculate, and pay the amount of tax liability by themselves. In order to ensure tax compliance, there should be an improvement to tax audit and tax investigation. Tax audit is performed by tax auditors to ensure a higher tax compliance rate is achieved under the SAS. The tax audit officers are required to ensure that the correct amount of income is reported and the right amount of tax is paid accordance with the tax laws and regulations. As tax auditors, they need to be professional, well mannered, trustworthy, honest and demonstrate integrity while performing their job. They also need to be knowledgeable to give explanations on the objectives of the tax audit and make fair assessment based on the rights and responsibilities of taxpayers. This is to ensure that the rights and interest of the taxpayers are protected. Moreover, as good tax auditors, they must show competencies in term of skills and knowledge to ensure they can meet their organization's objectives. However, what determine their tax audit effectiveness?

This study aims to examine the factors influencing tax audit effectiveness of the tax auditors in the Inland Revenue Department in Malaysia (IRBM). Specifically, this study examines whether audit case selection, supervision monitoring and auditors' characteristics influence tax audit effectiveness in of the tax auditors in the Inland Revenue Department in Malaysia. The findings in this study could assist IRBM in identifying factors contributing efficiency and competency among IRBM tax auditors. This may enhance further steps and actions to improve level competency among the IRBM's tax auditors to help achieve its aspiration to be the leading tax administrators in the world. The next section provides the literature review related to this study. This is followed by Section 3 that explains the research design and Section 4 that presents the results. The last section concludes this study.

\section{Literature Review}

\section{Tax Audit Effectiveness}

IRBM (2007) defined tax audit as an examination of a taxpayer's business records and financial affairs to ascertain the amount of tax due should be reported and paid are in accordance with tax laws and regulations. A tax audit is also defined as an examination of whether a taxpayer has correctly assessed and reported their tax liability and fulfilled other obligation (OECD, 2006). On the other hands, Koromilas (2013) defined tax audit is examines the accuracy of the submitted tax documents, so that the auditors can confirm the amount of tax due. Moreover, Pantelidis (2009) and Grampert (2009) described tax audit as the procedure of examining the degree to which taxpayers have properly prepared financial 
statements according to the existing tax legislation. Pantelidis (2009); Torres (2004) also described tax audit as an assessment of whether a taxpayer has correctly reported tax liabilities. Thus, the main purpose of tax audit is to encourage voluntary compliance to the tax laws and regulations and to ensure that a higher tax compliance rate is achieved under the SAS. In order to make sure this objective is achieved, IRBM officers are required to ensure that by the tax payers report the correct amount of income and the right amount of tax is paid in accordance the tax laws and regulations.

Several studies in the accounting literature have examined on tax audit effectiveness. For example, Chalu and Mzee (2018) studied the effectiveness of tax audit in Tanzania. They examined the factors influencing the effectiveness of tax audit in Tanzania. Their study collected data from 225 auditors in 23 tax regions in Tanzania and the data were collected using mailed questionnaire. The study found five main critical factors for audit effectiveness which are recommendations by management, adequacy of tax audit unit, taxpayer's attitude, application and regulations and standards for tax audit and leadership and tax policies for tax audit. It was concluded that some factors have a strong relationship with tax audit effectiveness, for example the availability and application of regulations and standards for tax audit and the adequacy of the tax audit unit. These are followed by the implementation of tax auditors' recommendations by management and taxpayers' attitudes towards tax audit. George, Theofanis and Konstantinos (2015) studied the relationship tax audit effectiveness, tax legislation and use of specialized information system tools in Greece. They found that effective information systems help tax auditors to track infringement and explains the complexity and constant changes in tax legislation, make it difficult for tax auditors to be effective in their work. As a result, the level of education, work experience and training of tax auditors are needed to enhance their ability to track tax infringements.

Another study on tax audit effectiveness was conducted by Ayalew (2014) who examined the factors affecting tax audit effectiveness in audit quality, organization setting, top management support, auditors attributes and organization independence of Bahir Dar City Revenue office in Ethiopia. Moreover, Ayalew (2014) study used two sets of questions; set question number one consists of 64 questions answered by tax auditors and set question number two consist 10 questions answer by taxpayers. On the other hand, Ayalew (2014) distributed 333 sets of questions and only 265 question survey was returned back; out of the 265 respondents, 8 were tax auditors and 247 were taxpayers. Thus, Ayalew (2014) concluded that audit quality, organisational setting, organisational independence, taxpayer attributes, as well as top management support as a linear combination, significantly influences tax audit effectiveness in the organisations studied.

\section{Audit Case Selection influencing Tax Audit Effectiveness}

Most of the tax authority in developing countries perform their tax audit by either random case selection or criteria/information selection system rather than use case sensitive data mining model. These two audit selection systems were preferred at her than using case sensitive data mining model (Andreoni et al, 1998). Each of these two audit selection systems has its own drawback. The major drawback of random selection is its equal treatment to honest and dishonest taxpayers, as probability of selection is same for both, while the criteria/information selection system has a drawback that it pre-supposes certain symptoms of non-compliance, which may actually be symptoms of other external factors such as change in economic situation or/and government regulations in that particular trade. In addition, the automated selection process helps tax authority and tax audit operations to be flexible to the 
nature of the cases, is also useful for reducing the discretion of tax authorities, it reduces face to face contact tax auditors with taxpayers, facilitate information exchange between regulatory authorities, facilities information and taxpayers document security by reducing the current accumulated filing and help to reach reasonable decision to ensure audit effectiveness (Said et al., 2013).

The cases for audit are selected through computer system based on risk analysis criteria. However, the selection of audit cases is not confined to the selection by the computerized system only, as cases can also be selected based on information received from various source. Audit cases are selected in the following manner. Selection is based on risk analysis; Information received from third party; selection based on specific industries; selection based on specific issues for a certain group of taxpayers, and based on location.

Based on OECD (2006), most tax administrations have developed audit strategies focusing on taxpayer's non-compliance risks. Based on this technique, the criteria abased on score given to each taxpayer, based on (a) certain attributes size, industry, compliance history and (b) Knowledge acquired during previous audit campaigns (whatever the selection strategy) to select non-compliance taxpayer. Ayalew (2014) explained that these techniques enable the tax administration to build several profiles of taxpayers and hence to identify those most likely not to comply with tax rules. However, this can be true only when the tax audit case selection process supported by tax auditing soft-ware and data mining technology. The risk assessment has to be made automatic via a new software and data mining technology. In view of this, the tax audit operation has to consider the following preconditions to select a case with a high magnitude to revenue loss:

According to Ayalew (2014), the ability to capture and maintain data that can be usefully manipulated and cross-examine is the foundation of a good case selection system. This, however, does not mean that time consuming reporting requirements need to be imposed on taxpayers and other institutions. As with any investment, the costs and benefits need to be considered (Hussain et al, 2019). The challenge is to collect data that can be related to risk indicators and be built into databases that can be used to support analysis and development of inferences about non-compliance. Data is usually readily available from taxpayers at various stages of tax administration, including registration, filling, audit and collection enforcement. The data can be used to build individual case histories or profiles, stratify the population into meaningful groups and develop business sector profiles. This enables tax administrators to "score" taxpayer characteristics as well as relate the compliance history of one taxpayer to others in comparative circumstances. Ayalew (2014) also suggested that data alone does not make a good case selection system. It must support with analysis with some risk criteria to select audit cases. Moreover, analysis can be in form of applying objective risk factors across the data sets, assessment of filling and paying compliance, level of deviation in reported figures across periods and/or different revenue declarations from group averages, relationship between sales and cost of sales, gross profit, expenses, payroll, net profit, tax payable, and refunds claimed and other risk indicators.

Mihret (2011) examined tax audit practices in Ethiopia and investigated the key problems in tax audit operation regarding the appropriateness of audit types used, audit rate, aptness of audit case selection methods and audit examination techniques used, and the experience and capability of audit staff resources. This study used questionnaires which distributed to 65 tax auditors and investigators but only 55 survey questionnaires were usable. There respondents were under the age category of less than 30 years and come from accounting, finance, management and economics backgrounds. In this study, 87.1 percent of 
the respondents replied that taxpayer have been selected based on their compliance risk (compliance risk indicators) for audit purpose. This study found that, audit case selection is based on information kept by taxpayers and other parties and auditors and investigators have good to access it. The study also found that taxpayer cooperation in term to giving essential information necessary for audit leads to tax audit effectiveness based on audit case selection. On the other hand, Ayalew (2014) studied the relationship between tax audit effectiveness and organizational tools and found that individual auditors are not able to select the taxpayers audit cases. Thus, a team committee will review some criteria like taxpayer's declaration, considering information about the taxpayer's compliance history, which is the criteria is risk criteria to be select as audit selection case using selection system. This study concluded that the taxpayers audit case selection is performed with a committee rather than an individual auditor for the purpose of fair and transparent audit case selection.

\section{Supervision Monitoring influencing Tax Audit Effectiveness}

Besides audit case selection, another factor determining tax audit effectiveness is supervision monitoring. The support and commitment of management helps tax auditors to work effectively. Furthermore, the success of tax auditors will depend on the strength of management's support in auditing process. There are limited studies on the relationship between supervision monitoring and tax audit effectiveness. A few studies have focused on the relationship between management supports with internal audit effectiveness. The finding supports the relationship between tax audit effectiveness and supervision monitoring. Alzeban and Sawan (2015) found that the support of top management, internal auditors can obtain sufficient resources to execute their duties and responsibilities, and the Internal Audit Department can hire qualified staff and provide continuous training and development. Moreover, how senior management support shows their support is a significant key to the role and value of tax auditors throughout an organization. Furthermore, management support helps empower tax auditors to execute their duties and fulfil their responsibilities.

Alzeban and Gwilliam (2017) studied the factor influencing internal audit effectiveness which is one of factor they study the relationship between management support and internal audit effectiveness. The study obtained data from 203 managers and 239 internal audits or from 79 Saudi Arabian public sector organizations. Alzeban and Gwilliam (2017) defined management support as linked to hiring trained and experiences staff, providing sufficient resources, enhancing the relationship with external auditors, and having an independent internal audit department. Meanwhile, Carcello et al (2005) explained that senior management have accorded increased importance to the audit function and changed their expectations of internal auditing. Hence, having supportive from top management, allow internal auditors to obtain sufficient resources to execute their duties and responsibilities, and the internal audit department also can hire qualified staff and provide continuous training and development (Alzeban \& Sayzwan, 2013). The study found that without management support, internal auditors lack independence, has limited scope of work and resources and have a poor relationship with the management. Hence, top management support is important in its own right and it is also linked to resourcing, competence and qualifications, independence, in audit effectiveness (Alzeban \& Gwilliam, 2017).

Shamki and Alhajri (2017) examined the extent to which internal audit effectiveness could be influenced by selected factors, like internal audit scope, internal auditors 's experience and senior management's response in the Omani public sector. Shamki and Alhajri (2017) study asked 48 questions to 45 managers and 163 employees in Oman. According 
Shamki and Alhajri (2017) there is an insignificant relationship between internal audit effectiveness and senior management's response. Thus, managers are well interest in organization's activities and performance depending on the internal audit findings and observations. On the other hand, according to Ayalew (2014), management support is important for tax audit effectiveness because it goes with resources and the commitment by management to implement tax audit recommendations to attain tax audit effectiveness.

\section{Tax Auditors' Characteristics influencing Tax Audit Effectiveness}

According OECD (2006), revenue bodies must manage and develop their audit workforce to deliver their planned outcomes through increasingly designing and implementing capability or competency models. Due to this reason, tax auditors' characteristic is one of main important reason for tax audit effectiveness among tax auditors in IRBM. In this research, tax auditors' characteristics mainly focused on their capability or competency Based on Mihret (2011), capability or competency models refers to a formal specification of the skills, knowledge and attributes of staff that are required to perform a specific job in an efficient and effective manner. Besides that, this model generally comprises of the job descriptions, functional descriptions, and competency profiles using task-related competencies. Moreover, normally is supported by training, exams and educational requirements to ensure and build capability (Voronkova et al., 2019), This model is used as a basis for managing performance, training, staff development, and recruitment across all audit functions (Mihret, 2011).

According to Ayalew (2014), tax auditors must be competent in terms of technical knowledge, audit skills, and good knowledge while according Mihret (2011), a good tax auditor requires higher level of skills than those needs for most other tax administration tasks, and such skills. Moreover, taxpayers may not deter from minimizing their tax liabilities if they believed that there is a possibility risk chance to be audited (Ebrill et al., 2001). Doda and Chinniah (2014) studied on factors affecting audit effectiveness in Hawassa City in Ethiopia, by using work experience as a variable. The study found that 90 percent of the respondent are tax auditors who agrees that tax audit quality was affected by education and work experience. Besides that, 80 percent of respondents have an experience of less than two years and it was revealed that education qualification and work experience affect the quality of tax audit. On the other hand, based on Mihret (2011) research tax audit practice in Ethiopia and one of variable is experience and capability of audit staff. The researcher distributed questionnaire to 65 tax auditors and investigators but only 55 survey respondents answer the question survey. The study found that 80 percent of respondents have no audit experience before they have employed in Ethiopia Revenue and Custom Authority (ERCA). Moreover, 80 percent of survey respondents have an experience of less than four years in their current position. The study concluded that auditors might be effective as the lack of experience and capable tax audit will increase complexity in tax audit. Thus, the lack capable and experienced audit staff would it create complexity in conducting audit cases.

\section{Research Design}

Sample Selection

The population of this study is the tax auditors working in IRBM. The process to determine the sample size of this study is known as simple random sampling since every person in the population has known and equal chance of being selected as a subject and also provide has the least bias and offers the most general liability (Sekaran \& Bougie, 2013). In 
determining the populations and sample size, the following steps suggested by Sekaran \& Bougie (2013). They proposed a rule of thumb for deciding the sample size such as samples sizes larger than 30 and less than 500 are appropriate or/and should be several times (preferably ten times or more) as large as the number of variables in the study that give more or less the same number of samples. Thus, this study decided to have a sample size of 300 .

\section{Research Instrument}

This study used questionnaire which is a widely used and useful instrument for collecting survey information. The questions in the questionnaires were adopted from previous studies. This study's questionnaire was distributed to determine the factor affecting the effectiveness of tax auditors working in IRBM's Petaling Jaya, Jalan Duta, and Large Tax Payer Branch. The first part is Part 1 which probes personal background, including education background, experience and number of training day. Part 2 focuses on tax effectiveness, Part focuses on audit case selection and lastly, Part 3 probes on supervision monitoring.

In Part 1, thirteen (13) questions were asked which is including branch, grade, tax audit department, audit experience, background education, level of education, age, working experience in IRBM and others. This question was adopted from Mihret (2011). Next, in Part 2 , the respondents were asked about tax effectiveness of tax auditors in Petaling Jaya. In this part, there were six (6) questions which were adopted from Doda and Chinniah (2014). Part 3 focuses on supervision monitoring and consists of six (6) questions adopted from (Gale \& Samwick, 2014).

\section{Data Collection}

Data were collected from copies of questionnaires sent to the respondents. The questionnaire was distributed by personally to the IRBM tax auditors through the human resource department. According to Sekaran and Bougie (2013), the main advantage of selfadministered questionnaire is that it allows the researcher or research team to collect completed responses within a short period of time. Besides that, any doubts from the respondents could be clarified immediately. The total number of questionnaires distributed was 300 sets. The respondents were given three days to complete the questionnaire. Out of the 300 questionnaires distributed, this study managed to collect 264 responses, resulting in a response rate of 88 percent.

\section{Results}

\section{Tax Audit Effectiveness}

Table 1 presents the descriptive statistics for tax audit effectiveness. The result shows that 67 percent of respondents agree that audit is performed based on audit manual with a mean score of 3.66. This is because normally, the tax auditors will use data analysis and use guideline from tax audit framework for their checking during audit. Besides that, the IRBM has imposed audit procedure for their tax auditors in term for auditing and investigation. A comprehensive audit manual is helpful for tax auditors to make sure that the tax auditors are consistent when dealing with taxpayers, and efficient. Meanwhile, 80.6 percent of the respondents agree that taxpayers can easily understand and aware of the rules forms gives significant to tax audit effectiveness with a mean score of 4.07. Therefore, taxpayer should aware and seek sources tax knowledge from IRBM websites, seminar and conferences. Taxpayer also should have tax knowledge by keeping proper record of documentation and tax law and regulations. 
Table 1 also shows that 95.5 percent of the respondents strongly agree that continuous and sufficient training for tax auditors is important for ensure tax audit effectiveness with a mean score of 4.43. In this regard, from the survey, 61.4 percent of respondents are attending training courses less than 16 days a year and 80.7 percent of respondents attend less than 5 times training a year. This shows that tax auditors should be fast learners in short time of period. Short courses lead to lack of understanding and dissatisfaction among tax auditors which will lead to inefficiency. Moreover, in order for a tax audit to be effective, 87.5 percent of respondents agree that IRBM should apply standard risk identification criteria to identify high risked business for audit with a mean score of 4.17. This is because tax auditors have to identify red flag issues based on manual data analysis. Besides that, the complexity of business transaction leads to tax auditors to understands the transactions and takes longer time to audit. Therefore, identifying standard risk will help to tax auditors to focus the issue for checking and lead to time efficiency.

This study also shows that 93.1 percent of respondent also agree that continuous assessment improves the capability or competency of staff resources, auditors and investigators with a mean score of 4.31. Thus, tax auditors in IRBM will be evaluated quarterly to see their performance in term to meet the objectivity of IRBM. Besides that, to encourage competency among tax auditors in IRBM, award and promotion will be given to tax auditors with the best performance. Ninety two percent of respondents agree that the audit works should be started and completed within a predetermined timeframe with a mean score of 4.33. As a result, tax auditors need to solve the case within three months, as mentioned in the tax audit framework (IRBM, 2018).

Table 1: Descriptive Analyses for Tax Audit Effectiveness

\begin{tabular}{|l|c|c|c|c|c|c|}
\hline & $\begin{array}{l}\text { Strongly } \\
\text { Disagree }\end{array}$ & Disagree & Niether & Agree & $\begin{array}{c}\text { Strongly } \\
\text { Agree }\end{array}$ & Mean \\
\hline $\begin{array}{l}\text { Audit is performed based on } \\
\text { audit manual }\end{array}$ & $5.7 \%$ & 15.9 & 11.4 & 40.9 & 26.1 & 3.66 \\
\hline $\begin{array}{l}\text { Taxpayers can easily } \\
\text { understand and aware of the } \\
\text { rules. }\end{array}$ & 0 & 0 & 19.3 & 54.5 & 26.1 & 4.07 \\
\hline $\begin{array}{l}\text { Continuous and sufficient } \\
\text { trainings for tax auditors. }\end{array}$ & 1.1 & 0 & 3.4 & 45.5 & 50 & 4.43 \\
\hline $\begin{array}{l}\text { Apply standard risk } \\
\text { identification criteria for } \\
\text { identify highly risky business } \\
\text { for audit. }\end{array}$ & 2.3 & 0 & 10.2 & 55.7 & 31.8 & 4.17 \\
\hline $\begin{array}{l}\text { A continuous assessment to } \\
\text { improve the capability or } \\
\text { competency of staff } \\
\text { resources, auditors and } \\
\text { investigators. }\end{array}$ & 1.1 & 0 & 5.7 & 54.5 & 38.6 & 4.31 \\
\hline $\begin{array}{l}\text { The audit work to be started } \\
\text { and completed within a } \\
\text { predetermined timeframe. }\end{array}$ & 0 & 0 & 8 & 51.1 & 40.9 & 4.33 \\
\hline
\end{tabular}




\section{Audit Case Selection}

Table 2 presents the descriptive statistics for audit case selection. The table shows that 76.5 percent of respondents agree tax auditors have good access to information held by the taxpayers and others with a mean score of 4.03 . Hence, it is important for tax auditors to have wide access information for example information from bank account, assets like luxury car and house. Tax auditors still have limited sources of information to access taxpayer.

Table 2: Descriptive Analyses for Audit Case Selection

\begin{tabular}{|l|c|c|c|c|c|c|}
\hline Description & $\begin{array}{c}\text { Strongly } \\
\text { Disagree }\end{array}$ & Disagree & Neither & Agree & $\begin{array}{c}\text { Strongly } \\
\text { Agree }\end{array}$ & Mean \\
\hline $\begin{array}{l}\text { Tax auditors have a good } \\
\text { access to information held by } \\
\text { the taxpayers and others }\end{array}$ & 0 & 0 & 23.9 & 48.9 & 27.3 & 4.03 \\
\hline $\begin{array}{l}\text { Taxpayers cooperate to give } \\
\text { essential information } \\
\text { necessary for performing an } \\
\text { audit }\end{array}$ & 0 & 0 & 19.3 & 62.5 & 18.2 & 3.99 \\
\hline $\begin{array}{l}\text { Taxpayers comply with the } \\
\text { tax system in Malaysia }\end{array}$ & 0 & 3.4 & 42 & 47.7 & 6.8 & 3.58 \\
\hline $\begin{array}{l}\text { Taxpayers are selected based } \\
\text { in their associated compliance } \\
\text { risk }\end{array}$ & 2.3 & 0 & 21.6 & 69.3 & 6.8 & 3.78 \\
\hline $\begin{array}{l}\text { Tax audit is sole treatment for } \\
\text { compliance risk available to } \\
\text { IRBM }\end{array}$ & 3.4 & 0 & 30.7 & 59.1 & 6.8 & 3.69 \\
\hline $\begin{array}{l}\text { Cooperation from taxpayer } \\
\text { gives significant for cases } \\
\text { settlement in three months }\end{array}$ & 0 & 0 & 11.4 & 62.5 & 26.1 & 4.15 \\
\hline $\begin{array}{l}\text { Best communication with } \\
\text { taxpayer gives significant for } \\
\text { case settlement }\end{array}$ & 0 & 0 & 11.4 & 62.5 & 26.1 & 4.25 \\
\hline $\begin{array}{l}\text { Business sector gives } \\
\text { significant for fast case } \\
\text { settlement }\end{array}$ & 0 & 0.7 & 63.6 & 30.7 & 4.03 \\
\hline
\end{tabular}

Other than that, 80.7 percent of respondents, with a mean score of 3.99 agreed if taxpayers cooperate to give essential information necessary for performing an audit. Of consequence, tax auditors will get information and more understand the nature of business operation and transaction. Other than that, 54.5 percent of respondents, with a mean score of 3.58 agreed that if taxpayers comply with the tax system in Malaysia. Besides that, 76.1 percent of respondent with a mean score of 3.78 agreed that taxpayers are selected based in their associated compliance risk. Meanwhile, 65.9 of respondents, with a mean score of 3.69 agreed that tax audit is a sole treatment for compliance risk available to IRBM. Next, 88.6 percent of respondents, with mean score of 4.15 agreed that cooperation from taxpayer gives significant for cases settlement in three months. Table 2 also shows that 88.6 percent of respondents with a mean score of 4.25 agreed that the communication with taxpayer is significant for case settlement. Lastly, 94.3 percent of respondents, with a mean score of 4.03 
agreed that business sector gives significant for fast case settlement. In other words, complexity of business transactions affects in time efficiency for tax auditors in solving a case.

\section{Supervision Monitoring}

Table 3 presents the descriptive statistics for supervision monitoring. Based on the survey, 95.5 percent of respondents with a mean score of 4.33 agreed that the senior management supports tax auditors to perform its duties and responsibilities. For that reason, participation of senior management is important in term of efficiency of tax audit. This is because most promotions to senior management are based on their performance and because of their performance and experience will especially help junior tax auditors to find the audit issue. For case settlement, 91 percent of respondents, with a mean score of 4.24 agreed that senior management are involved in the audit planning. This is because based on tax audit procedure, tax auditors must get approval from supervisors for audit planning before proceeding to conduct an audit visit.

Table 3: Descriptive Analyses for Supervision Monitoring

\begin{tabular}{|l|c|c|c|c|c|c|}
\hline & $\begin{array}{c}\text { Strongly } \\
\text { Disagree }\end{array}$ & Disagree & Neutral & Agree & $\begin{array}{c}\text { Strongly } \\
\text { Agree }\end{array}$ & Mean \\
\hline $\begin{array}{l}\text { Senior management supports } \\
\text { tax auditors to perform its } \\
\text { duties and responsibilities }\end{array}$ & 0 & 0 & 4.5 & 58 & 37.5 & 4.33 \\
\hline $\begin{array}{l}\text { Senior management are } \\
\text { involved in the audit planning }\end{array}$ & 0 & 0 & 9.1 & 58 & 33 & 4.24 \\
\hline $\begin{array}{l}\text { Tax auditors provide senior } \\
\text { management with sufficient, } \\
\text { reliable and relevant reports } \\
\text { about the work they perform } \\
\text { and recommendations made }\end{array}$ & 0 & 0 & 8 & 52.3 & 39.8 & 4.32 \\
\hline $\begin{array}{l}\text { Senior Management suggest } \\
\text { issues audit to the tax } \\
\text { auditors before raised audit } \\
\text { findings }\end{array}$ & 1.1 & 6.8 & 23.9 & 39.8 & 28.4 & 3.88 \\
\hline $\begin{array}{l}\text { My superior always helps in } \\
\text { term for case settlement }\end{array}$ & 0 & 2.3 & 10.2 & 59.1 & 28.4 & 4.14 \\
\hline $\begin{array}{l}\text { My superior needs me to } \\
\text { report my performance } \\
\text { monthly }\end{array}$ & 1.1 & 4.5 & 12.5 & 53.4 & 28.4 & 4.03 \\
\hline $\begin{array}{l}\text { My superior monitor my aging } \\
\text { case and help me to settle } \\
\text { aging case }\end{array}$ & 0 & 1.1 & 12.5 & 65.9 & 20.5 & 4.06 \\
\hline
\end{tabular}

Table 3 also shows that 92.1 percent of respondents, with a mean score of 4.32 agreed that tax auditors provide senior management with sufficient, reliable, and relevant reports about the work they perform and recommendations made. In fact, tax auditors should provide and prepare financial statement analysis, detailed background of company, and other information on their tax audit planning before getting approval from their supervisors. Sixty two percent of respondents, with a mean score of 3.88 agreed that senior management 
suggests auditing issue to the tax auditors before increasing audit findings. In addition, again participant from superior is important for tax audit to be more efficient. Besides that, 87.5 percent of respondents, with a mean score of 4.14 agreed that their superiors always help them in case settlement.

This study also shows that 81.4 percent of respondents, with a mean score of 4.03 agreed that my superior needs me to report my performance monthly. Last but not least, 86.4 percent of the respondents, with a mean score of 4.06 agreed that their superior monitor their aging case and help them to settle aging case.

\section{Tax Auditors' Characteristics}

Besides the importance educational background, having an appropriate experience is also significant in order to be a good tax auditor. As shown in Table 4, 44.3 percent of respondents have no experience working as auditors before joining IRBM, while 55.7 percent of the respondents have hardworking experience.

Experience background is important for the tax auditors because their job scope needs them to have skills in tax rules, regulation, communication skills, analysis skills and others. According to Badara and Saidin (2013), auditing experience is strongly associated to the different levels of knowledge and skills that the auditors has acquired as a result of long job practice in auditing professions in a way that can enhance effectiveness. Hence, to be a good tax auditor, experience is significant for effective in tax audit.

Table 4 also shows that 61.4 percent of the respondents have attended less than 16 days for the training courses in a year, while 38.6 percent of the respondents have attended more than 16 days of training. From the survey, we can also see that 80.7 percent of the respondents have attended training less than 5 times a year, while 19.2 percent of the respondents have attended more than six training courses a year. Moreover, besides educational background and experience, training is also important to make sure tax auditors is competent and up to date with changes in the environment and technologies. From the survey, we can conclude that tax auditors in IRBM attend training courses in short period. Therefore, as tax auditors in IRBM, they should build capacity through training for a short period of time and as fast learners to be competent tax auditors.

From the survey, 28.4 percent of the respondents have between more than 4 years experience as auditors, while 37.5 percent of respondent has less than 4 years of auditing experience. Based on international standard, a good tax auditors should have at least two and above years of experience, therefore, from the survey, most of the tax auditors have experience of at least two years and above. Thus, it can be seen that most of the tax auditors fulfil the international standards in terms of experience background. 
Table 4: Descriptive Statistics for Tax Auditors' Characteristics

\begin{tabular}{|c|c|c|c|}
\hline Audit Experience before joining IRBM & $\begin{array}{c}\text { Frequen } \\
\text { cy }\end{array}$ & $\begin{array}{c}\text { Valid } \\
\text { Percent }\end{array}$ & $\begin{array}{l}\text { Cumulativ } \\
\text { e Percent }\end{array}$ \\
\hline Yes & 147 & 55.7 & 55.7 \\
\hline No & 117 & 44.3 & 100 \\
\hline How long have u been working as an auditor? & $\begin{array}{l}\text { Frequen } \\
\text { cy }\end{array}$ & $\begin{array}{l}\text { Valid } \\
\text { Percent }\end{array}$ & $\begin{array}{l}\text { Cumulativ } \\
\text { e Percent }\end{array}$ \\
\hline No & 117 & 44.3 & 44.3 \\
\hline Less than 2 years & 21 & 8 & 52.3 \\
\hline $2-4$ years & 54 & 19.3 & 71.6 \\
\hline 4-6 years & 30 & 11.4 & 83 \\
\hline $6-10$ years & 27 & 10.2 & 93.2 \\
\hline Above 10 years & 18 & 6.8 & 100 \\
\hline How long have you been working with IRBM? & $\begin{array}{c}\text { Frequen } \\
\text { cy }\end{array}$ & $\begin{array}{c}\text { Valid } \\
\text { Percent }\end{array}$ & $\begin{array}{l}\text { Cumulativ } \\
\text { e Percent }\end{array}$ \\
\hline Less than 2 years & 12 & 4.5 & 4.5 \\
\hline $2-4$ years & 36 & 13.6 & 18.2 \\
\hline 4-6 years & 57 & 21.6 & 39.8 \\
\hline $6-10$ years & 69 & 26.1 & 65.9 \\
\hline Above 10 years & 90 & 34.1 & 100 \\
\hline Total number of days taken for courses in a year & $\begin{array}{c}\text { Frequen } \\
\text { cy }\end{array}$ & $\begin{array}{c}\text { Valid } \\
\text { Percent }\end{array}$ & $\begin{array}{l}\text { Cumulativ } \\
\text { e Percent }\end{array}$ \\
\hline Less than 16 days & 162 & 61.4 & 61.4 \\
\hline 16-30 days & 69 & 26.1 & 87.5 \\
\hline $31-60$ days & 24 & 9.1 & 96.6 \\
\hline more 60 days & 9 & 3.4 & 100 \\
\hline $\begin{array}{l}\text { How many times have you attended training courses in } \\
\text { a year? }\end{array}$ & $\begin{array}{l}\text { Frequen } \\
\text { cy }\end{array}$ & $\begin{array}{l}\text { Valid } \\
\text { Percent }\end{array}$ & $\begin{array}{l}\text { Cumulativ } \\
\text { e Percent }\end{array}$ \\
\hline Less than 5 & 213 & 80.7 & 80.7 \\
\hline $6-10$ & 45 & 17 & 97.7 \\
\hline $10-15$ & 3 & 1.1 & 98.9 \\
\hline more than 15 & 3 & 1.1 & 100 \\
\hline
\end{tabular}

\section{Preliminary Tests}

Table 5 presents the reliability testing. The result shows that the reliability value is 0.782 , indicating that the items used in this study are reliable.

Table 5: Reliability Statistics

\begin{tabular}{|c|c|c|}
\hline Cronbach's Alpha & $\begin{array}{c}\text { Cronbach's Alpha Based on } \\
\text { Standardized Items }\end{array}$ & N of Items \\
\hline 0.782 & 0.836 & 30 \\
\hline
\end{tabular}

Based on Table 6, the data normality according to the value Kolmogorov-Smirnov, Skewness and Kurtosis. The test of skewness is to check the normality and the outliers of the data. Based on Table 6, it can be concluded that the data are normally distributed for Tax Audit Effectiveness, Audit Case Selection, Supervision Monitoring and Tax Auditor's Characteristics. 
Table 6: Normality Test on Variables

\begin{tabular}{|l|c|c|c|}
\hline \multicolumn{1}{|c|}{ Variables } & $\begin{array}{c}\text { Kolmogorov- } \\
\text { Smirnov }\end{array}$ & $\begin{array}{c}\text { Skewness ( } \mathrm{p}- \\
\text { value) }\end{array}$ & Kurtosis \\
\hline Tax Audit Effectiveness & 0.124 & 0.117 & -0.197 \\
\hline Audit Case Selection & 0.131 & 0.297 & 0.245 \\
\hline Supervision Monitoring & 0.184 & 0.264 & -0.951 \\
\hline Tax Auditors' Characteristics & 0.156 & 0.362 & -0.213 \\
\hline
\end{tabular}

Collinearity diagnostics were conducted before multiple regression procedure can be done. This is used to prove there is no issue on correlation matrix for independent variable as presented in Table 7, labelled as Collinearity Statistics. There are two values given, Tolerance and Variance Inflation Factor (VIF). According to Pallant (2011), the degree of Tolerance must not less than 0.19 and the degree of VIF must not be more than 10. From the result in Table 7, the Tolerance values of IV1 IV2 and IV3were 0.772, 0.777, and 0.957, respectively, which are greater than 0.19, while the VIF values of IV1 , IV2 and IV3, were 1.295, 1.287 and 1.045, respectively, which are less than 10 . Since both variables meet the tolerance and VIF requirements, multicollinearity issue does not affect the model.

Table 7: Multicollinearity Test Result

\begin{tabular}{|l|l|r|r|}
\hline \multirow{2}{*}{ Model } & \multicolumn{2}{|c|}{ Collinearity Statistics } \\
\cline { 3 - 4 } & Total Audit Case Selection & Tolerance & VIF \\
\cline { 3 - 4 } & Total Supervision Monitoring & .772 & 1.295 \\
\hline & Total Tax Audit Characteristics & .777 & 1.287 \\
\hline & & .957 & 1.045 \\
\hline
\end{tabular}

a. Dependent Variable: Total Tax Audit Effectiveness

\section{Pearson's Correlation}

Table 8 shows that results of the Pearson's Correlation analysis for all variables used in this study (Hinkle et. Al, 2003). The results show that all variables are associated with each other with the strongest relationship was noted between Total Audit Case Selection and Total Supervision Monitoring, with the value of 0.465 units. 
Table 8: Correlation Analyses

\begin{tabular}{|c|c|c|c|c|c|}
\hline & & $\begin{array}{c}\text { Total Tax } \\
\text { Audit } \\
\text { Effectiveness }\end{array}$ & $\begin{array}{c}\text { Total Tax } \\
\text { Audit } \\
\text { Characteristics }\end{array}$ & $\begin{array}{c}\text { Total } \\
\text { Audit } \\
\text { Case } \\
\text { Selection }\end{array}$ & $\begin{array}{c}\text { Total } \\
\text { Supervision } \\
\text { Monitoring } \\
\end{array}$ \\
\hline \multirow{2}{*}{$\begin{array}{l}\text { Total Tax } \\
\text { Audit } \\
\text { Effectiveness } \\
\text { (DV) }\end{array}$} & $\begin{array}{l}\text { Pearson } \\
\text { Correlation }\end{array}$ & 1 & .022 & $.423^{* *}$ & $.381^{* *}$ \\
\hline & $\begin{array}{l}\text { Sig. (2- } \\
\text { tailed) }\end{array}$ & & .841 & .000 & .000 \\
\hline \multirow{2}{*}{$\begin{array}{l}\text { Total Audit } \\
\text { Case Selection } \\
\text { (IV1) }\end{array}$} & $\begin{array}{l}\text { Pearson } \\
\text { Correlation }\end{array}$ & $.423^{* *}$ & -.186 & 1 & $.465^{* *}$ \\
\hline & $\begin{array}{l}\text { Sig. (2- } \\
\text { tailed) }\end{array}$ & .000 & .083 & & .000 \\
\hline \multirow{2}{*}{$\begin{array}{l}\text { Total } \\
\text { Supervision } \\
\text { Monitoring } \\
\text { (IV2) }\end{array}$} & $\begin{array}{l}\text { Pearson } \\
\text { Correlation }\end{array}$ & $.381^{* *}$ & -.167 & $.465^{* *}$ & 1 \\
\hline & $\begin{array}{l}\text { Sig. (2- } \\
\text { tailed) }\end{array}$ & .000 & .120 & .000 & \\
\hline \multirow{2}{*}{$\begin{array}{l}\text { Total Tax } \\
\text { Audit } \\
\text { Characteristics } \\
\text { (IV3) }\end{array}$} & $\begin{array}{l}\text { Pearson } \\
\text { Correlation }\end{array}$ & .022 & 1 & -.186 & -.167 \\
\hline & $\begin{array}{l}\text { Sig. (2- } \\
\text { tailed) }\end{array}$ & .841 & & .083 & .120 \\
\hline
\end{tabular}

**. Correlation is significant at the 0.01 level (2-tailed).

\section{Multiple Regression Analysis}

Table 9 presents the results of multiple regression analysis that shows the multiple $R$ (correlation) value of $0.487(48.7 \%)$. This indicates that low positive relationship between dependent and independent variables and $\mathrm{R}$ Square value for the model showed that $23.7 \%$ of the dependent variable in the model can be predicted by the independent variables. As the $\mathrm{R}$ square value is 0.27 , which is less than 0.5 , we conclude there is a weak linear relationship for all other model. However, from the ANOVA report in Table 10 shows that the model is significant as $p$-value is less than 0.05 .

Table 9: Model Summary ${ }^{b}$

\begin{tabular}{|l|rr|r|r|r|}
\hline Model & R & R Square & $\begin{array}{r}\text { Adjusted } \\
\text { R Square }\end{array}$ & $\begin{array}{r}\text { Std. Error of } \\
\text { the Estimate }\end{array}$ \\
\hline 1 & & $.487^{\mathrm{a}}$ & .237 & .210 & 1.960 \\
\hline
\end{tabular}

a.Predictors: (Constant), Total Supervision Monitoring, Total Tax Audit

Characteristics, Total Audit Case Selection

b. Dependent Variable: Total Tax Audit Effectiveness

\begin{tabular}{|l|l|r|r|r|r|}
\hline \multicolumn{2}{|c|}{ Model } & Sum of Squares & \multicolumn{1}{c|}{$\begin{array}{c}\text { Mean } \\
\text { Square }\end{array}$} & \multicolumn{1}{c|}{$\mathrm{F}$} & \multicolumn{1}{c|}{ Sig. } \\
\hline \multirow{2}{*}{1} & Regression & 100.237 & 33.412 & 8.698 & $.000^{\mathrm{b}}$ \\
\cline { 2 - 6 } & Residual & 322.661 & 3.841 & & \\
\cline { 2 - 6 } & Total & 422.898 & & & \\
\hline
\end{tabular}


Based on Table 11, the result shows that audit case selection has the most significant impact on tax audit effectiveness compared to tax audit characteristics and supervision monitoring. Based on the result shown in Table 11, all predictors are positively related to dependent variable. Thus, the model for predicting perceived tax audit effectiveness is:

$$
Y_{i}=11.665 \text { (Constant) }+0.233 x_{1 i}+0.130 X_{2 i}+0.163 X_{3 i}
$$

$\mathrm{X}_{1 \mathrm{i}}=$ Audit Case Selection

$\mathrm{X}_{2 \mathrm{i}}=$ Supervision Monitoring

$\mathrm{X}_{3 \mathrm{i}}=$ Tax Auditor's Characteristics

The result indicates that the-value (beta coefficient) indicates the positive relationship between audit case selection, supervision monitoring and tax auditors' characteristics. In the case of audit case selection, supervision monitoring and tax auditors' characteristics is good and tax audit effectiveness has also been improved.

Table 11: Coefficients ${ }^{\mathrm{a}}$

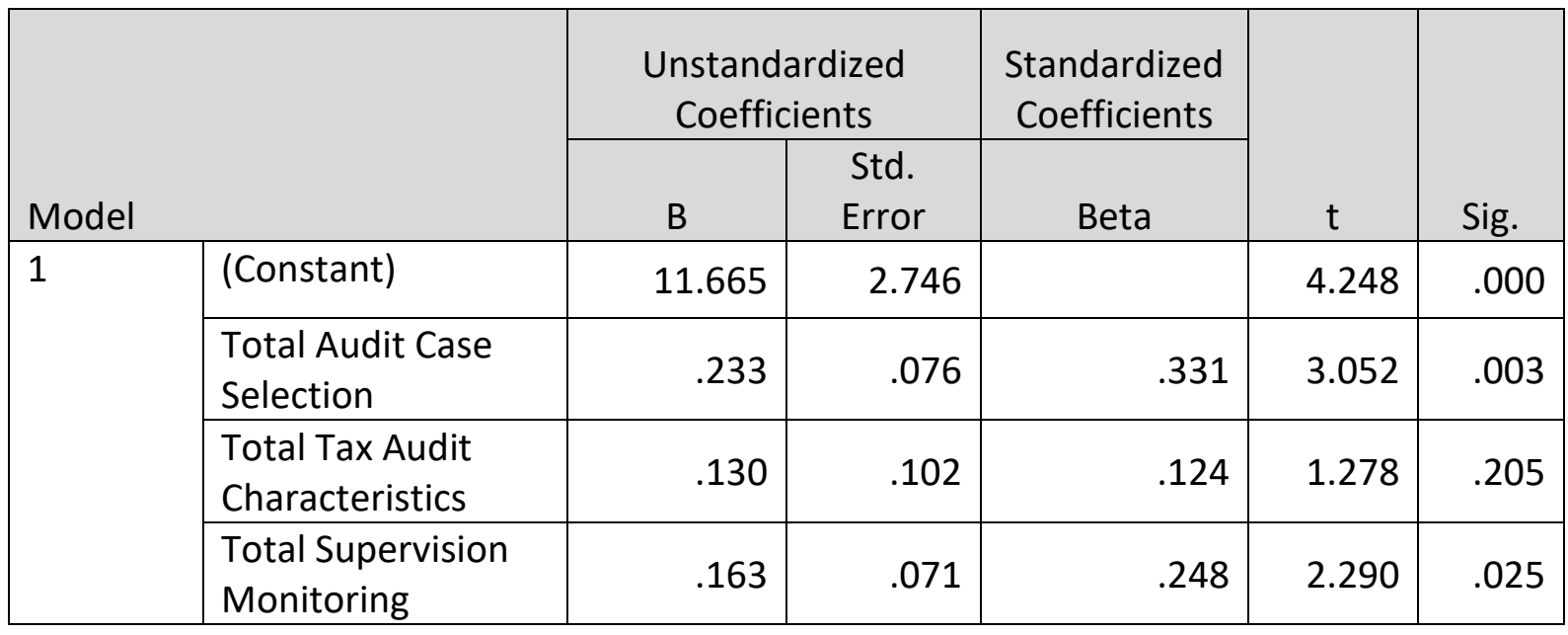

a. Dependent Variable: Total Tax Audit Effectiveness

\section{Conclusion}

This study examines the factors influencing tax audit effectiveness of the tax auditors in IRBM. Three factors are chosen which subsequently formed the three research hypotheses. First, this study shows that the audit case selection has a positive effect on tax audit effectiveness. Therefore, hypothesis 1 is accepted. The previous study also presented a positive relationship between audit case selection and the dependent variable (Ayalew, 2014). The second independent variable is supervision monitoring which also has a positive effect on tax audit effectiveness. As a result, hypothesis 2 is accepted. Besides that, the previous study also showed the positive relation between supervision monitoring with tax audit effectiveness (Shamki \& Alhajri, 2017). The third independent variable is tax auditors' characteristics which shows positive effect on tax audit effectiveness. Therefore, hypothesis 3 is accepted. Moreover, previous study also showed the positive relation between tax auditors' characteristics with the dependent variables (Doda \& Chinniah, 2014).

There are several limitations in this study, first there were only 264 completed questionnaires analysed, hence, the sample size is small. The limitation was also due to time constraints which are the instrument are distributed within a week into three branches and 
the respondents have to give feedback within a week to respond. Consequently, how respondents answer the questionnaire might be affected by the time constraint faced by the respondents. Moreover, the instrument only focused on tax auditors and future studies should also consider taxpayer perception on tax audit effectiveness. Therefore, future study should also include taxpayers' perception of tax audit effectiveness. Besides that, other independent variables can be considered on future studies, for example, business sector, time length to settle the case, the amount collected based on audit findings and taxpayers' satisfaction from case settlement. This is because, in order to be efficient and effective, IRBM should consider fairness and transparency to the public and also a taxpayer.

This study is significant to IRBM as it could help tax administrators to monitor IRBM's tax auditors to increase their efficiency. The results are expected to assist IRBM in identifying factors contributing efficiency and competency among IRBM tax auditors. This may enhance further steps and actions to improve level competency among the IRBM's tax auditors to help achieve its aspiration to be the leading tax administrators in the world. It will also help IRBM to consider the suggestion and recommendation in order to produce good and competence tax auditors in the future.

\section{References}

Alzeban, A., Sawan, N. (2015), The impact of audit committee characteristics on the implementation of internal audit recommendations, Journal of International Accounting, Auditing and Taxation, 24(C), pp. 61-71

Alzeban, A., Gwilliam, D. (2014), Factors affecting the internal audit effectiveness: A survey of the Saudi public sector, Journal of International Accounting, Auditing and Taxation, 23(2), pp. 74-86

Andreoni, J., Erard, B., Feinstein, J. (1988), Tax compliance, Journal of Economic Literature, 36(2), pp. 818-860

Ayalew, E. (2014), Factors affecting tax audit effectiveness: A study on category A taxpayers in Bahir Dar City Administration Revenue Office, Masters Thesis, Bahir Dar University

Badara, M. S., Saidin, S. Z. (2013), The relationship between audit experience and internal audit effectiveness in the public sector organisations, International Journal of Academic Research in Accounting, Finance and Management Sciences, 3(3), pp. 329-339

Carcello, J. V., Hermanson, D. R., Raghunandan, K. (2005), Changes in internal during the time of the major US accounting scandals, International Journal of Auditing, 9(2), pp. 117127

Chalu, H., Mzee, H. (2018), Determinants of tax audit effectiveness in Tanzania, Managerial Auditing Journal, 33(1), pp. 35-63

Doda, N. B., Chinniah, A. (2014), Assessment of tax audit practice: A case study of Hawassa City administration revenue authority, Hawassa, Ethiopia, CLEAR IJRMST, 4(8), pp. 1-16

Ebrill, L., Keen, M., Bodin, J. P., Summers, V. (2001). The Modern VAT. Washington, D.C.: International Monetary Fund.

Gale, W. G., Samwick, A. A. (2014), Effects of income tax changes on economic growth, Economic Studies, September, pp. 1-16

Ghani, E. K., Said, J. (2010), Digital reporting practices among Malaysian local authorities, Electronic Journal of E Government, 8(1), pp. 33-44

George, D., Theofanis, K., Konstantinos, A. (2015), Factors associated with internal audit effectiveness: Evidence from Greece, Journal of Accounting and Tax, 7(7), pp. 113-122

Grampert M (2002). Tax audit, Swedish National Tax Board, www.worldbank.org 
Hussain, H. I., Ghani, E. K., Razimi, M. S. A. (2019), Systematic risk and determinants of cost of capital: An empirical analysis of selected case studies, Journal of Security and Sustainability Issues, 9(1), 295-307

IRBM. (2007), Annual Report, http://phl.hasil.gov.my/pdf/pdfam/AR2007_2.pdf

Koromilas, G. (2013). Tax notes, Athens: Tax Advisors.

OECD. (2006), The changing tax compliance environment and the role of audit, https://www.oecd.org/tax/administration/the-changing-tax-compliance-environmentand-the-role-of-audit-9789264282186-en.htm

Mihret, G. (2011), Tax audit practice in Ethiopia: The case of the federal government, Masters Thesis, Addis Ababa University

Pallant, J. (2011) SPSS survival manual: A step by step guide to data analysis using the SPSS program. 4th Edition, Allen \& Unwin, Berkshire.

Pantelidis, P. (2009). Conceptual Framework of Auditing. Tax Audit Approach, International Journal of Managerial Research Technology, 3(2), pp. 409-416.

Said, J., Ghani, E. K., Omar, N., Yusuf, S. N. S. (2013), Money laundering prevention measures among commercial banks in Malaysia, International Journal of Business and Social Science, 4(5), pp. 227-235

Sapiei, N. S., Kasipillai, J. (2013). External tax professionals' views on compliance behaviour of corporation. American Journal of Economics, 3(2), pp. 82-89.

Shamki, D., Alhajri, T.A. (2017), Factors influence internal audit effectiveness, 12(10), International Journal of Business and Management, 12(10), pp.143-153

Singh, V., Bhupalan, R. (2001) The Malaysian self-assessment system of taxation: Issues and Challenges. ibusiness, 8(1), 12-17.

Torres, P. (2004). Opinion poll about tax audit. Management Auditing Journal. 19(8), pp. 9791005.

Voronkova, O., Hordei, O., Barusman, A. R. P., Ghani, E. K. (2019), Social integration as a direction for humanisation of economic relations and improvement of social welfare, SocioEconomic Challenges, 3(4), pp. 52-63 